\title{
Effect of Mix Culture Bacteria and Fungi in Fermented Peanut Hulls-Based Feed Supplement on Physical Quality and In Vitro Rumen Fermentation Parameters
}

\author{
Nesti DR*, Baidlowi A, Fauzi A, Tjahajati I \\ Departement of Bio-resource and Veterinary Technology, Vocational College, Gadjah Mada University \\ E-mail address: delarianesti87@gmail.com
}

(received 10-12-2019; revised: 12-02-2020; accepted: 13-02-2020)

\begin{abstract}
ABSTRAK
Nesti DR, Baidlowi A, Fauzi A, Tjahajati I. 2020. Pengaruh kombinasi campuran bakteri dan jamur pada kualitas fisik fermentasi pakan suplemen berbasis kulit kacang terhadap kualitas fisik dan parameter fermentasi rumen secara in vitro . JITV 25(1): 25-31. DOI: http://dx.doi.org/10.14334/jitv.v25i1.2079.

Penelitian ini bertujuan untuk mengetahui pengaruh kombinasi campuran bakteri (EM4:E) dan jamur (Trichoderma viridae:TV) sebagai inokulan pada fermentasi pakan suplemen berbasis kulit kacang terhadap kualitas fisik dan parameter fermentasi rumen secara in vitro. Pakan Basal (PB) dibagi kedalam empat perlakuan, yaitu: $\mathrm{P}_{0}(\mathrm{~PB}) ; \mathrm{P}_{1}(\mathrm{E}: 25 \%+\mathrm{TV}: 75 \%) ; \mathrm{P}_{2}$ (E:50\%+TV:50\%); dan $\mathrm{P}_{3}$ (E:75\%+TV:25\%), setiap perlakuan menggunakan tiga kali ulangan. Pakan difermentasi selama sembilan hari secara fakultatif anaerob. Parameter yang diamati meliputi kualitas fisik pakan (warna, aroma, kenampakan jamur, dan $\mathrm{pH}$ ) serta parameter fermentasi rumen secara in vitro ( $\mathrm{pH}$ rumen, kadar protein mikrobia, dan kadar total asam lemak terbang). Data dianalisis dengan menggunakan rancangan acak lengkap pola searah (One-way ANOVA), jika terdapat perbedaan nyata dilanjutkan dengan uji Kruskall-Wallis untuk data kualitas fisik dan uji Duncan's New Multiple Range Test (DMRT) untuk data parameter fermentasi dalam rumen secara in vitro. Hasil penelitian menunjukkan bahwa kombinasi E dan TV dengan perbandingan yang berbeda tidak mempengaruhi parameter aroma dan kenampakan jamur pada parameter kualitas fisik $(\mathrm{P} \geq 0,05)$, tetapi berpengaruh nyata $(\mathrm{P} \leq 0,05)$ terhadap perubahan warna dari coklat kehitaman $(1,64)$ pada $\mathrm{P}_{0}$ menjadi warna kecoklatan pada $P_{1}, P_{2}$ dan $P_{3}$ berturut-turut: 2,44; 2,69; dan 2,80, serta penurunan $\mathrm{pH}$ berturut-turut: 10,67; 10,67 dan 10,67\%, dari $\mathrm{P}_{0}$. Kombinasi inokulum dengan perbandingan yang berbeda tidak memberikan pengaruh nyata $(\mathrm{P} \geq 0,05)$ terhadap parameter $\mathrm{pH}$ rumen, kadar protein mikrobia dan kadar total VFA. Berdasarkan hasil penelitian dapat disimpulkan bahwa fermentasi suplemen pakan berbasis kulit kacang dengan kombinasi $\mathrm{EM}_{4}{ }^{\circledR} 25 \%$ :Trichoderma viridae $75 \%$ memberikan hasil terbaik dalam parameter kualitas fisik pakan fermentasi ditinjau dari warna serta $\mathrm{pH}$ dengan tidak menggangu parameter fermentasi dalam rumen.
\end{abstract}

Kata Kunci: $\mathrm{EM}_{4}{ }^{\circledR}$, Fermentasi Rumen secara In Vitro, Kulit Kacang Tanah, Kualitas Fisik, Trichoderma viridae

\section{ABSTRACT}

Nesti DR, Baidlowi A, Fauzi A, Tjahajati I. 2020. Effect of Mix Culture Bacteria and Fungi in Fermented Peanut Hulls-Based Feed Supplement on Physical Quality and In vitro Rumen Fermentation Parameters. JITV 25(1):25-31. DOI: http://dx.doi.org/10.14334/jitv.v25i1.2079.

The purpose of this research was to determine the effect of the combination of mix culture bacteria (EM4®:E) and fungi (Trichoderma viridae:TV) on physical quality and in vitro rumen fermentation parameters of peanut hull-based feed supplements. Basal feed was divided into four treatments, which were: P0 (BF); P1 (E:25\%+TV:75\%); P2 (E:50\%+TV:50\%); and P3 (E:75\%+TV:25\%); and each treatment had three replications. Feeds were fermented facultative anaerobically for nine days. The observed parameters were physical qualities (color, odor, fungi appearance and $\mathrm{pH}$ ), and in vitro rumen fermentation parameters (rumen $\mathrm{pH}$, microbial protein content, and total volatile fatty acid content). Data were analyzed using one way ANOVA design, and the significance of differences were tested using Kruskall-Wallis test for the physical qualities data and Duncan's New Multiple Range Test (DMRT) test for in vitro rumen fermentation parameters. Results showed that the combination of $\mathrm{E}$ and $\mathrm{TV}$ at different level did not affect odor and the fungi appearance parameters $(\mathrm{P} \geq 0.05)$, however, it significantly affected $\mathrm{P} \leq 0.05$ ) color change from blackish (1.64) in P0 to brownish in P1, P2 and P3 of 2.44; 2.69; and 2.80, respectively. The $\mathrm{pH}$ also decreased significantly $(\mathrm{P} \leq 0.05)$ by $10.67 \%$. Treatment also did not affect the rumen $\mathrm{pH}$, microbial protein content, and total volatile fatty acid content $(\mathrm{P} \geq 0.05)$. It is concluded that the combination of the EM4® $25 \%$ : Trichoderma viridae $75 \%$ on peanut-hull based feed supplement fermentation gives the best result on color and $\mathrm{pH}$ fermented feed product without affecting the rumen fermentation process.

Key Words: $\mathrm{EM}_{4}{ }^{\circledR}$, In Vitro Rumen Fermentation, Peanut Hull, Physical Quality, Trichoderma viridae 


\section{INTRODUCTION}

In Indonesia, the availability of forages as feed sources for ruminants during the dry season is very limited, so the role of agriculture-based waste or byproducts was very important as an alternative feed source. One of the potential feedstuffs from agriculture wastes is the peanut hulls. According to the Kementerian Pertanian Republik Indonesia (2019), Indonesia might produce approximately 512.198 tons of peanuts. The problem of peanut hulls as a feed ingredient is that it contains relatively high crude fiber $(61,99 \%)$, and low $(8.74 \%)$ crude protein (Fauzi 2019), which limits its digestibility (Tillman et al. 1991). Technology intervention could be used to improve the nutrient contents of peanut hull, such as supplementation with other feedstuffs or nutrients and through the fermentation process (Natsir 2012). Feed supplements can support the development of rumen microbes and improve feed digestibility (Wina 2005; Pamungkas et al. 2008), while fermentation process might improve the feed quality, due to the involvement of microbes in digesting and fermenting fiber (cellulose, hemicellulose) and anti-nutrient compounds (Rokhmani 2005).

Trichoderma viridae is a fungus which produce cellulolytic enzyme, which degrades complex polysaccharides into simple polysaccharides and improve the fiber digestibility (Jaelani et al. 2015). Rizali et al. (2018) showed in their research that the utilization of Trichoderma viride on the fermentation process of palm oil midrib and leaves might decrease crude fiber content by up to $8.81 \%$. EM $4{ }^{\circledR}$ is a mix culture of bacteria, consisting mainly of five genus: Rhodopseudomonas sp., Lactobacillus sp. Streptomyces sp., Actinomycetes, and Saccharomices sp (Casmia 2016; Santoso \& Aryani 2007); Satria \& Nurhasanah 2010), that capable of degrading crude fiber and improve its digestibility (Ismanto 2018). Telew et al. (2013) showed in their research that EM4 decreased crude fiber content of rice hulls up to $24 \%$. Lokapirnasari et al. (2015) explained in their study using the combination of bacteria Acidothermus cellulolyticus and Aspergillus terreus might decrease crude fiber content on rice bran fermentation.

According to the potential of peanut-hull and the bacteria and fungi as an inoculant source for feed fermentation, this research was conducted to evaluate the effects of combinations of mix culture bacteria and fungi on the physical and fermentation characteristics of peanut hull.

\section{MATERIALS AND METHODS}

\section{Feed preparation and formulation}

Peanut hull as the main feedstuff for this research is obtained from local farmers in Kulon Progo Regency, Yogyakarta Province, Indonesia. Other feedstuffs are obtained from PT. Hasta Karya Damai Manunggal, Boyolali Regency, Central Java, Indonesia. Peanut hull was finely ground and then mixed with other ingredients such as: palm kernel meal, copra meal, pollard, corn gluten meal, minerals, molasses and urea. The feed formulation and nutrient contents is shown in Table 1. Trichoderma viride was obtained from the Pusat Antar Universitas (PAU), Universitas Gadjah Mada and EM $4{ }^{\circledR}$ was obtained from Sleman Regency Yogyakarta Province, Indonesia.

\section{Inoculum preparation}

Trichoderma viridae (pure) was cultured using Potato Dextrose Agar (PDA) media and re-cultured using Potato Dextrose Broth (PDB) media. Cultures were stored for 5 days at $37^{\circ} \mathrm{C}$ incubators, then counted using a spectrophotometer on $600 \mathrm{~nm}$ to find out the fungal cells count. The use of the fungi inoculant on this research is on the liquid state. The cell count of the solution EM $4{ }^{\circledR}$ was counted using a spectrophotometer on 600nm (Syauqi 2017). The use of the EM4 is prepared directly when ready to use in.

\section{Feed supplements fermentation and treatment groups}

Water content (WC) of formulated feed supplements was adjusted to $60 \%$ using a mix of water and inoculums. $2 \%$ of inoculum on the liquid state, from total water-used to produce $60 \% \mathrm{WC}$ is mixed with subtracted water-inoculum water. Each treatment was weighed $(250 \mathrm{~g})$ and was fermented using $2 \mathrm{~kg}$ plastic bags silos. Fermented feed supplements were divided into four groups of treatments, in three replications:

$\mathrm{P}_{0}$ : Basal feed

$\mathrm{P}_{1}: \mathrm{P}_{0}+$ Trichoderma viridae $(75 \%)+\mathrm{EM}_{4}{ }^{\circledR}(25 \%)$

$\mathrm{P}_{2}: \mathrm{P}_{0}+$ Trichoderma viridae $(50 \%)+\mathrm{EM}_{4}{ }^{\circledR}(50 \%)$

$\mathrm{P}_{3}: \mathrm{P}_{0}+$ Trichoderma viridae $(25 \%)+\mathrm{EM}_{4}{ }^{\circledR}(75 \%)$

Oxygen was sucked from the silo using vacuum tools. Silos already in anaerobic conditions were then inserted with the needle in a loose plastic section that was closed with cotton in order to form a facultative anaerobic condition. The fermentation process lasted for 9 days (Mirwan 2018).

\section{Physical quality test}

The physical qualities observed in this study were color, odor, fungi appearance and $\mathrm{pH}$ base on (Irawati et al. 2019). The determination of the physical quality of feed supplements was conducted by 15 reliable panelists. Feed fermentation results were taken as much as 50 grams and were placed in a small cup. Tests were conducted based on the scoring and then the data obtained was transformed into a numerical scale, as follows: 
Table 1. Formulation and nutrient contents of experimental feedstuffs

\begin{tabular}{lccccc}
\hline \hline Feedstuff & Formulation $(\%)$ & DM $(\%)$ & CP $(\%)$ & CF $(\%)$ & EE $(\%)$ \\
\hline Peanut hull $^{1}$ & 50 & 49.63 & 4.37 & 30.9 & 0.29 \\
Pollard $^{2}$ & 5 & 4.30 & 0.82 & 0.29 & 0.20 \\
Palm kernel cake $^{2}$ & 15 & 12.90 & 2.12 & 1.61 & 1.79 \\
Copra cake $^{2}$ & 12 & 10.32 & 3.31 & 0.82 & 1.35 \\
$\mathrm{CGF}^{3}$ & 10 & 8.60 & 2.38 & 0.67 & 0.20 \\
Urea $^{3}$ & 1 & 0.86 & 2.88 & 0.00 & 0.00 \\
Molasses $^{3}$ & 5 & 3.85 & 0.20 & 0.02 & 0.02 \\
Minerals $^{3}$ & 2 & 1.72 & 0.00 & 0.00 & 0.00 \\
\hline Total & 100 & 92.18 & 10.8 & 35.7 & 5.87 \\
\hline
\end{tabular}

${ }^{\mathrm{T}}$ Fauzi (2019), ${ }^{2}$ Hartadi et al. (2017), ${ }^{3} \mathrm{NRC}(2001)$

$\mathrm{DM}=$ Dry matter, $\mathrm{CP}=$ Crude protein, $\mathrm{CF}=$ Crude fiber, $\mathrm{EE}=$ Ether Extract

Table 2. Laboratory analysis of nutrient contents of experimental fermented feed

\begin{tabular}{lcccc}
\hline \hline Groups & DM $(\%)$ & CP $(\%)$ & CF $(\%)$ & NFE $(\%)$ \\
\hline $\mathrm{P}_{0}$ & 96.52 & 16.12 & 33.48 & 39.45 \\
$\mathrm{P}_{1}$ & 95.50 & 16.12 & 39.17 & 33.90 \\
$\mathrm{P}_{2}$ & 95.50 & 15.98 & 38.41 & 34.27 \\
$\mathrm{P}_{3}$ & 95.53 & 15.73 & 38.31 & 34.68 \\
\hline
\end{tabular}

$\mathrm{P}_{0}=$ Basal feed, $\mathrm{P}_{1}=\mathrm{P}_{0}+$ Trichoderma viride $(75 \%)+\mathrm{EM} 4^{\circledast}(25 \%), \mathrm{P}=\mathrm{P}_{0}+$ Trichoderma viride $(50 \%)+\mathrm{EM} 4^{\circledast}(50 \%), \mathrm{P}_{3}=\mathrm{P}_{0}+$ Trichoderma viride $(25 \%)+\mathrm{EM}^{\oplus}{ }^{\circledast}(75 \%), \mathrm{DM}=$ Dry matter, $\mathrm{CP}=$ Crude protein, $\mathrm{CF}=$ Crude fiber, NFE $=$ Nitrogen Free Extract

1. Color: Score 1=blackish brown; score 2=chocolate; score 3=brownish yellow; score 4=yellow.

2. Odor: Score $1=$ very bad; score $2=$ rather rotten; score $3=$ slightly acidic; score $4=$ acid.

3. Pathogenic fungi appearance: Score 1=lots of fungi; Score $2=$ middle fungi; score $3=$ no fungi

\section{Fermented feed product $\mathrm{pH}$}

One gram of fermented feed was diluted with nine $\mathrm{ml}$ of aquadest and $\mathrm{pH}$ was determined using $\mathrm{pH}$ Meter (AOAC 2006).

\section{In vitro rumen fermentation}

In vitro rumen fermentation using the method of Menke \& Steingass (1988) as modified by Makkar et al. (1995). Samples (300 mg) were weighed and mixed with $30 \mathrm{ml}$ rumen: buffer solution (1:2) (vol/vol) and incubated for 48 hours. Gas production was measured at $0 ; 2 ; 4 ; 6 ; 8 ; 12 ; 24$; and 48 incubation hours. After 48 hours of incubation, samples were separated between filtrate and the supernatant by filtration. The filtrate used for rumen $\mathrm{pH}$ was $\mathrm{pH}$ Meter (Kim et al. 2019), rumen microbial protein using Lowry's method
(Plummer 1978), and VFA determination using gas chromatography (Filípek \& Dvořák 2009).

\section{Statistical analysis}

The experiment was arranged in a Completely Randomized Design and data were analyzed using the ANOVA. Data were processed using the SPSS version 16.0 program. The significance of difference among the treatment means was tested using Kruskall-Wallis test for the physical qualities data and the Duncan's New Multiple Range Test (DMRT) test for in vitro rumen fermentation parameters.

\section{RESULTS AND DISCUSSION}

\section{Physical quality}

Effect of the combinations of $\mathrm{EM} 4^{\circledR}$ and Trichoderma viridae fungi in fermented peanut hullsbased feed supplements on the physical quality and fermented product's $\mathrm{pH}$ is shown in Table 3 .

The inoculum combination of $\mathrm{EM} 4{ }^{\circledR}$ and Trichoderma viridae fungi in fermented peanut hullsbased feed significantly changed $(\mathrm{P} \leq 0.05)$ the 
fermented feed color value parameter between $\mathrm{P}_{0}$ group (brown) and $\mathrm{P}_{1}, \mathrm{P}_{2}$ and $\mathrm{P}_{3}$ groups (yellowish). The color change might be caused by microorganism's metabolism which degraded organic matter in the feed during the fermentation process. Microorganism's fermentation produced heat during the process that might affect the color of the fermented products. Munawaroh \& Anggraini (2017) reported that the change in color of fermentation treatment was caused not only by the influence of temperature during the fermentation process but also by the type of raw material. Yunianta \& Hartatik (2015) cited from Sianipar \& Simanihuruk (2009), explained in their study that the silage without inoculum might have a darker color because the living in the early phase of active aerobic respiration, degradation of organic matter produces water, $\mathrm{CO}_{2}$ and heat and the increasing temperature might affect the color of the silage.

The addition of different level combinations of EM4 ${ }^{\circledR}$ and Trichoderma viridae fungi in the peanut hulls-based fermented feed did not change the odor parameter $(\mathrm{P} \geq 0.05)$. The results showed that the average value of the odor of supplement food in each treatment has a slightly acidic interpretation. This slight acidic odor might come from substrates degradation by the microorganism. The $\mathrm{P}_{1}, \mathrm{P}_{2}$; and $\mathrm{P}_{3}$ groups showed higher acidic odor value compared to the $\mathrm{P}_{0}$ group. The addition of inoculum may have caused changes in carbohydrates and their derivative compounds to alcohol, acids, and carbon dioxide. Munawaroh et al. (2015) reported in her study that during the fermentation process there is a conversion of glucose to pyruvic acid and then to lactic acid. The production of these lactic acids might cause the aroma of fermentation to become acidic.

The addition of different level combinations of EM $4{ }^{\circledR}$ and Trichoderma viridae fungi in the peanut hulls-based fermented feed did not show any differences in the pathogenic fungi appearance parameter $(\mathrm{P} \geq 0.05)$. This could happen because Trichoderma viridae fungi used the substrates and prevent the usage of it by other pathogenic fungi. It could be proven by the change of the color and odor parameter. Yunianta \& Hartatik (2015) reported that the Trichoderma fungi appearance is significantly risen linearly with the fermentation time on corn straw fermentation using Trichoderma fungi. Trichoderma $s p$. might suppress the growth of pathogenic fungi by the antibiosis process, competition on substrates usage with the other pathogens fungi, and its hyper-parasitic traits which will lyse other pathogens fungi's hyphae (Purwantisari \& Hastuti 2009).

The addition of different level combinations of $\mathrm{EM} 4{ }^{\circledR}$ and Trichoderma viridae resulted in the differences in $\mathrm{pH}$ between the $\mathrm{P}_{0}$ groups $(\mathrm{P} \leq 0.05)$ and $\mathrm{P}_{1}, \mathrm{P}_{2}$, and $\mathrm{P}_{3}$ (Table 4). It might occur because both inoculums have the ability to degrade organic substrates and produce lactic acid that decreased the $\mathrm{pH}$ of the

Table 3. The effect of the combinations of EM $4{ }^{\circledR}$ and Trichoderma viridae fungi in fermented peanut hulls-based feed supplement on the physical quality and fermented product's $\mathrm{pH}$

\begin{tabular}{lcccc}
\hline \multirow{2}{*}{ Parameter } & \multicolumn{3}{c}{ Treatment } \\
\cline { 2 - 5 } & $\mathrm{P}_{0}$ & $\mathrm{P}_{1}$ & $\mathrm{P}_{2}$ & $\mathrm{P} 3$ \\
\hline Color $^{*}$ & $1.64^{\mathrm{a}}$ & $2.44^{\mathrm{b}}$ & $2.69^{\mathrm{b}}$ & $2.80^{\mathrm{b}}$ \\
Odor $^{(\mathrm{ns})}$ & 2.98 & 3.22 & 3.29 & 3.36 \\
Fungi $^{\text {(ns) }}$ & 3.00 & 3.00 & 3.00 & 3.00 \\
$\mathrm{pH}^{*}$ & $7,5^{\mathrm{a}}$ & $6,7^{\mathrm{b}}$ & $6,7^{\mathrm{b}}$ & $6,7^{\mathrm{b}}$ \\
\hline
\end{tabular}

$\mathrm{P}_{0}=$ Basal feed, $\mathrm{P}_{1}=\mathrm{P}_{0}+$ Trichoderma viride $(75 \%)+\mathrm{EM} 4^{\circledast}(25 \%), \mathrm{P}=\mathrm{P}_{0}+$ Trichoderma viride $(50 \%)+\mathrm{EM} 4^{\circledast}(50 \%), \mathrm{P}_{3}=\mathrm{P}_{0}+$ Trichoderma viride $(25 \%)+\mathrm{EM}^{\circledast}(75 \%)$

Table 4. The effect of the combination of EM $4^{\circledR}$ and Trichoderma viridae fungi in the fermented peanut hullsbased feed supplement to in vitro rumen parameters

\begin{tabular}{lcccc}
\hline \hline \multirow{2}{*}{ Parameter } & \multicolumn{3}{c}{ Treatment } \\
\cline { 2 - 5 } & $\mathrm{P} 0$ & $\mathrm{P} 1$ & $\mathrm{P} 2$ & $\mathrm{P} 3$ \\
\hline $\mathrm{pH}^{\mathrm{ns}}$ & 6,76 & 6,74 & 6,77 & 6,73 \\
${\text { Rumen Microbial protein }(\mathrm{mg} / 100 \mathrm{ml})^{\mathrm{ns}}}_{\text {Total VFA }^{\mathrm{ns}}}$ & 8,97 & 9,37 & 11,54 & 10,19 \\
\hline
\end{tabular}

$\mathrm{P}_{0}=$ Basal feed, $\mathrm{P}_{1}=\mathrm{P}_{0}+$ Trichoderma viride $(75 \%)+\mathrm{EM} 4{ }^{\circledR}(25 \%), \mathrm{P}=\mathrm{P}_{0}+$ Trichoderma viride $(50 \%)+\mathrm{EM}^{\circledR}(50 \%), \mathrm{P}_{3}=\mathrm{P}_{0}+$ Trichoderma viride $(25 \%)+\mathrm{EM} 4{ }^{\circledR}(75 \%),{ }^{\mathrm{ns}}=$ non-significant, VFA= Volatile Fatty Acid 


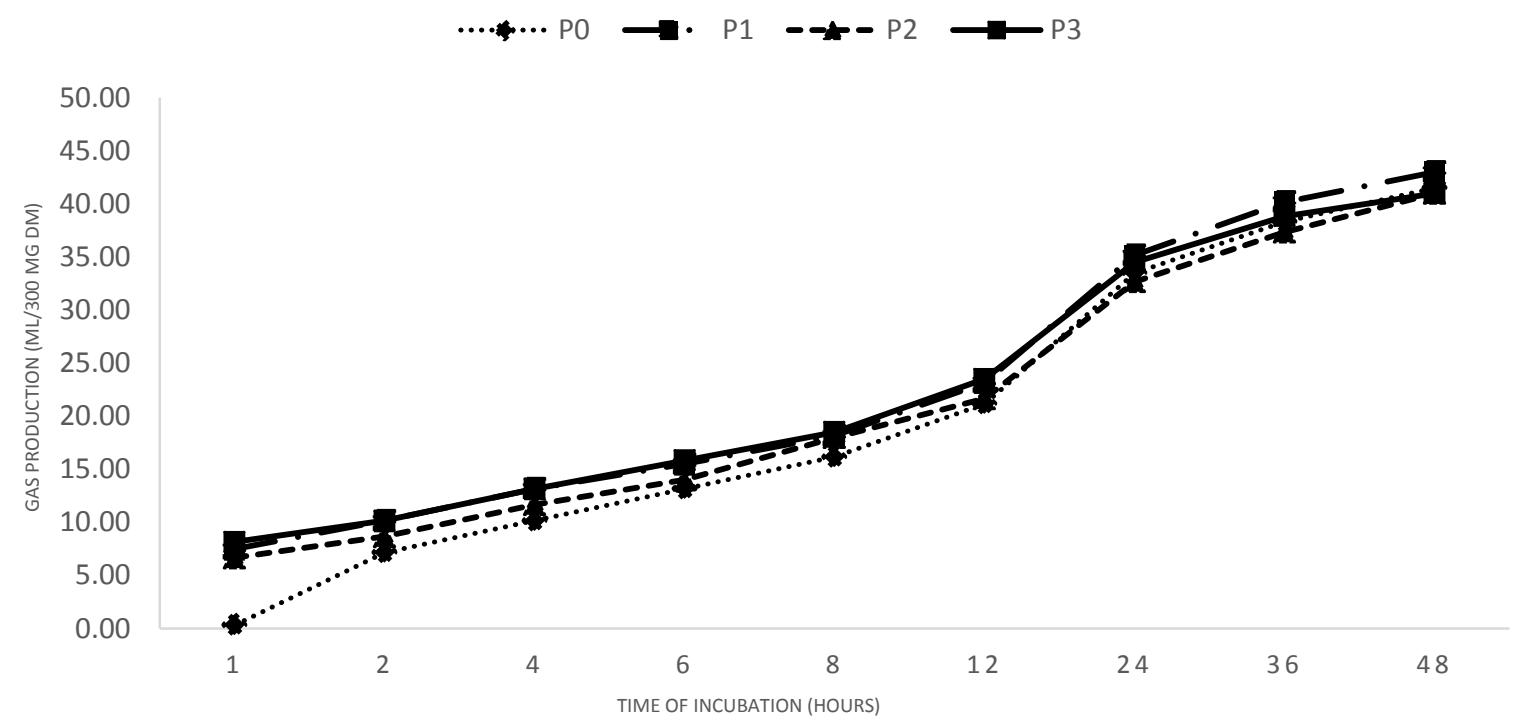

Figure 1. In vitro Gas production value of four different groups of the combination of EM4 ${ }^{\circledast}$ and Trichoderma viridae fungi in the fermented peanut hulls-based feed supplement: $\mathrm{P}_{0}=$ Basal Feed; $\mathrm{P}_{1}=\mathrm{P}_{0}+$ Trichoderma viride $(75 \%)+\mathrm{EM} 4{ }^{\circledR}(25 \%) ; \mathrm{P}_{2}=\mathrm{P}_{0}+$ Trichoderma viride $(50 \%)+\mathrm{EM} 4^{\circledR}(50 \%) ;$ and $\mathrm{P}_{3}=\mathrm{P}_{0}+$ Trichoderma viride $(25 \%)+\mathrm{EM} 4^{\circledR}(75 \%)$.

fermented product. The optimal $\mathrm{pH}$ for the growth of Lactobacillus bacteria, which one of the bacteria on EM4, was 6,8 (Pramono et al. 2003) and Trichoderma viridae was 6,2 (Juliana et al. 2017). Zakaria et al. (2013) stated that the more colonies of lactic acid bacteria grew in the fermentation process, the fermentation process will result in lower $\mathrm{pH}$. Trichoderma viridae fungi produce alcohol during the fermentation process while $\mathrm{EM}_{4}{ }^{\circledR}$ produced lactic acid as a by-product of the fermentation process (Umrah et al. 2009). Wahono et al. (2011) reported that in their research using $\mathrm{EM}_{4}{ }^{\circledR}$ : organic acids like acetic acid, pyruvic acid, and lactic acid decreased $\mathrm{pH}$ strongly, while other acids, such as butyric acid and other fatty acids had only a slight effect decrease in $\mathrm{pH}$.

\section{In vitro fermentation}

In vitro gas production value of four different groups of the combination of EM $4{ }^{\circledR}$ and Trichoderma viridae fungi in the fermented peanut hulls-based feed supplement are shown in Figure 1. Gas production illustrates the activity of microbes in degrading feed in the rumen. The results showed that incubation timecorrelated with gas production and there was no significant difference $(\mathrm{P} \geq 0.05)$ between $\mathrm{P} 0, \mathrm{P} 1 \mathrm{P} 2$ and $\mathrm{P} 3$ groups on in vitro gas production. The gas production might not significantly different because the formulation, feed ingredients and nutritional content between the groups are slightly the same. Microbial rumen can ferment all types of feed ingredients and the role of the microbes in ruminants was very important because $65 \%$ of the main feed of ruminants is degraded by rumen microbes (Firsoni \& Lisanti 2017). AboDonia et al. (2014) presented in his research that fungal using Trichoderma viride and urea might increase the gas production of peanut hull in vitro parameter because Trichoderma and urea might loosen the ligno-cellullose bonds and increase the solubility of hemicellulose and the soluble fraction.

The effect of the combination of $\mathrm{EM} 4{ }^{\circledR}$ and Trichoderma viridae fungi in the fermented peanut hulls-based feed supplement to in vitro rumen parameters is showed in Table 3 . The result showed that the addition of a different level combination of EM $4^{\circledR}$ and Trichoderma viridae fungi in the fermented peanut hulls-based feed did not show any differences in rumen $\mathrm{pH}$ after in vitro test $(\mathrm{P} \geq 0.05)$. The rumen $\mathrm{pH}$ is at normal condition indicating that the fermented feed did not affect the rumen $\mathrm{pH}$ condition, even though the fermented $\mathrm{pH}$ is slightly acidic. The $\mathrm{pH}$ of the feed product did not affect the rumen $\mathrm{pH}$ because it's on the normal range of rumen $\mathrm{pH}$, which is 6.0-7.0. Mardalena (2015) stated that the normal $\mathrm{pH}$ rumen was a key factor for optimal rumen function. The change in rumen $\mathrm{pH}$ will affect the microbial population and further affect the digestibility of feed.

Rumen microbial protein content was not affected by the addition of a different level combination of EM $4{ }^{\circledR}$ and Trichoderma viridae fungi in the fermented peanut hulls-based feed $(\mathrm{P} \geq 0.05)$. It could occur because of the supply rate of carbohydrate and nitrogen amount. The crude protein content on the fermented peanut hull feed using EM4 and Trichoderma fungi might play the role of the rumen microbial protein content. Abo-Donia et al. (2014) explained that 
fermentation using fungi treatment might decrease $\mathrm{NH}_{3}-$ $\mathrm{N}$ release, and carbohydrate was degraded to provide energy for microbial multiplication resulting microbial mass and N-balance increase.

Total VFA content was not affected by the addition of different level combinations of EM $4{ }^{\circledR}$ and Trichoderma viridae fungi in the fermented peanut hulls-based feed $(\mathrm{P} \geq 0.05)$. McDonald et al. (2002) stated that the average normal VFA production was 70$150 \mathrm{mM}$, while in this study the total VFA produced ranged from 107.79 to $135.30 \mathrm{mM}$. It may be related to a similar amount of complex carbohydrate and protein substrates from fermented feed used by rumen microbes in rumen fermentation. Nurjana et al. (2015) explained that the ensiling process using Trichoderma reesei on napier grass did not affect the VFA content due to the high content of low digestible saccharides and crude protein in the napier grass fermented product.

\section{CONCLUSION}

The inoculum combination of $\mathrm{EM} 4^{\circledR}$ and Trichoderma viridae fungi in fermented peanut hullsbased feed supplement gives accepted physical quality of fermented feed product. Color, odor, and fungi appearance met the requirements of good fermented feed. It also gives no negative effect on in vitro rumen fermentation parameters such as $\mathrm{pH}$, rumen microbial protein content and total VFA content. However the combination of Trichoderma viridae $(75 \%)+\mathrm{EM}_{4}{ }^{\circledR}$ $(25 \%)$ gives the best result in color and $\mathrm{pH}$ parameters while it does not affect the rumen $\mathrm{pH}$, rumen microbial and VFA parameters.

\section{REFERENCES}

Abo-Donia FM, Abdel-Azim SN, Elghandour MMY, Salem AZM, Buendía G, Soliman NAM. 2014. Feed intake, nutrient digestibility and ruminal fermentation activities in sheep-fed peanut hulls treated with Trichoderma viride or urea. Trop Anim Health Prod. 46:221-228.

[AOAC]. Association of Official Analytical Chemists. 2006 Official Methods of Analysis. 18th ed. Horwitz W, Latimer G, editors. Maryland (US): Association of Official Analytical Chemists International Gaithersburg.

Casmia R. 2016. Pengaruh Dosis Inokulum dan Lama Fermentasi Campuran Kulit Kakao dan Ampas Tahu Dengan EM-4 terhadap Kandungan dan Kecernaan Serat Kasar serta Energi Metabolisme: Padang (Indones): University of Andalas.

Fauzi A. 2019. Pengaruh kombinasi jamur Trichoderma viride dan EM-4 terhadap kualitas fisik dan kimia suplemen pakan fermentasi berbasis kulit kacang tanah (Arachis Hypogeae L.). Yogyakarta (Indones): Mercu Buana University.
Filípek J, Dvořák R. 2009. Determination of the volatile fatty acid content in the rumen liquid: comparison of gas chromatography and capillary isotachophoresis. Acta Vet Brno. 78:627-633.

Firsoni F, Lisanti E. 2017. Potensi pakan ruminansia dengan penampilan produksi gas secara in vitro. J Peternak Indones. 19:140-148.

Indonesia KPR. 2019. Data 5 tahun terakhir Sub-sektor Tanaman Pangan, Produksi Kacang Tanah Menurut Provinsi tahun 2014-2018. [cited 2020 Feb 15].: https://www.pertanian.go.id/home/?show=page\&act=vi ew\&id=61

Irawati E, Purnamasari E, Arsyad F. 2019. Kualitas fisik dan nutrisi eceng gondok (Eichornia crassipes) dengan lama fermentasi yang berbeda. J Peternak. 16:18-24.

Ismanto D. 2018. Penggunaan efektif mikroorganisme 4 (Em4) pada pakan terhadap konsentrasi asam lemak volatil dan amonia cairan rumen sapi Sumbawa. Mataram (Indones): University of Mataram.

Jaelani A, Widaningsih N, Mindarto E. 2015. Pengaruh lama penyimpanan hasil fermentasi pelepah sawit oleh Trichoderma $s p$ terhadap derajat keasaman $(\mathrm{pH})$, kandungan protein kasar dan serat kasar. Ziraa'ah. 40:232-240.

Juliana, Umrah, Asrul. 2017. Pertumbuhan miselium Trichoderma sp. pada limbah cair tempe dan limbah air kelapa. Biocelebes. 12:52-59.

Kim JN, Song J, Kim EJ, Chang J, Kim C-H, Seo S, Chang MB, Bae G-S. 2019. Effects of short-term fasting on in vivo rumen microbiota and in vitro rumen fermentation characteristics. Asian-Australiasian J Anim Sci. 32:776782 .

Lokapirnasari WP, Setiawan A, Prawesthirini S. 2015. Potensi kombinasi bakteri dan jamur selulolitik pada fermentasi bekatul terhadap kandungan serat kasar dan protein kasar. Bul Peternak. 39:174-179.

Makkar HPS, Blümmel M, Becker K. 1995. Formation of complexes between polyvinyl pyrrolidones or polyethylene glycols and tannins, and their implication in gas production and true digestibility in vitro techniques. Br J Nutr. 73:897-913.

Mardalena M. 2015. Evaluasi serbuk kulit nanas sebagai sumber antioksidan dalam ransum kambing perah peranakan etawah secara in vitro. J Ilm Ilmu-Ilmu Peternak. 18:14-21.

McDonald P, Edwards R, Greenhalgh J. 2002. Animal Nutrition. New York (USA): Prentice Hal.

Menke H, Steingass H. 1988. Estimation of the energetic feed value obtained from chemical analysis and in vitro gas production using rumen fluid. Anim Res Dev. 2:7-55.

Mirwan. 2018. The effect of fermentation time with Trichoderma viride on the value of fraction of peanut hulls fiber (Arachis hypogeae L): Yogyakarta (Indones): Mercu Buana University. 
Munawaroh F, Anggraini L. 2017. Aplikasi Trichoderma $s p$ terhadap kualitas fermentasi limbah daun angsana (Pterocarpus indicus Wild). In: Seminar Nasional Peneliti Univ Kanjuruhan Malang. Malang (Indones): Universitas Kanjuruhan Malang.

Munawaroh LL, Budisatria IGS, Suwignyo B. 2015. Pengaruh pemberian fermentasi complete feed berbasis pakan lokal terhadap konsumsi, konversi pakan, dan feed cost kambing Bligon jantan. Bul Peternak. 39:167-173.

Natsir A. 2012. Fibre Utilization by Ruminants. Makassar (Indones): Masagena Press.

Nurjana DJ, Suharti S, Suryahadi S. 2015. Improvement of napier grass silage nutritive value by using inoculant and crude enzyme from Trichoderma reesei and its effect on in vitro rumen fermentation. Media Peternak. 39:46-52.

Pamungkas D, Anggaraeni YK, Krishna N. 2008. produksi asam lemak terbang dan amonia rumen sapi Bali pada imbangan daun lamtoro (L. Leucocephala) dan pakan lengkap yang berbeda. In: Sani Y, Martindah E Nurhayati, Puastuti W, Sartika T, Parede L, Anggraeni A, Natalia L, editors. Semin Nas Teknol Peternak dan Vet. Bogor (Indones): Pusat Penelitian dan Pengembangan Peternakan.

Plummer D. 1978. An Introduction to Practical Biochemistry. Bombay (India): Tata McGraw Hill Publ. Co. Ltd.

Pramono YB, Harmayani E, Utami T. 2003. Growth kinetics of Lactobacillus plantarum and Lactobacillus sp. in MRS medium. J Teknol dan Ind Pangan. 14:46-50.

Purwantisari S, Hastuti R. 2009. Uji antagonisme fungi patogen phytophthora infestans penyebab penyakit busuk daun dan umbi tanaman kentang dengan menggunakan Trichoderma spp isolat lokal. BIOMA. $11: 24-32$.

Rizali A, Fachrianto F, Ansari MH, Wahdi A. 2018. Pemanfaatan limbah pelepah dan daun kelapa sawit melalui fermentasi Trichoderma sp. sebagai pakan sapi potong. EnviroScienteae. 14:1-7.

Rokhmani S. 2005. Peningkatan nilai gizi bahan pakan dari limbah pertanian melalui fermentasi. Proceeding Lokakarya Nasional Potensi dan Peluang Pengembangan Usaha Agrobisnis. In: Lokakarya Nasional Potensi dan Peluang Pengembangan Usaha Agribisnis Kelinci. Bogor (Indones): Pusat Penelitian dan Pengembangan Peternakan.
Santoso U, Aryani I. 2007. Perubahan Komposisi Kimia Daun Ubi Kayu yang Difermentasi oleh EM4. J Sain Peternak Indones. 2:53-56.

Satria H, Nurhasanah. 2010. Degradasi lignin oleh isolat lokal Actinomycetes pada substrat limbah jerami padi. J Sains MIPA. 16:135-142.

Sianipar J, Simanihuruk K. 2009. Performans kambing sedang tumbuh yang mendapat pakan tambahan mengandung silase kulit buah kakao. In: Semin Nas Teknol Peternak dan Vet. Bogor (Indones): Pusat Penelitian dan Pengembangan Peternakan.

Syauqi A. 2017. Penentuan kuantitas sel Saccharomyces cerevisiae dengan turbidimetri. e-JBST. 2:1-9.

Telew C, Kereh V, Untu I, Rembet B. 2013. Pengayaan nilai nutritif sekam padi berbasis bioteknologi "Effective Microorganisms" (EM4) sebagai bahan pakan organik. J Zootek. 32:1-8.

Tillman A, Hartadi H, Reksohadiprodjo S, Prawirokusumo S, Lebdosoekojo S. 1991. Ilmu Makanan Ternak Dasar. 5th ed. Yogyakarta (Indones): Gadjah Mada University Press.

Umrah, Anggraini T, Esyanti RR, Aryantha INP. 2009. Antagonitas dan efektifitas Trichoderma $s p$ dalam menekan perkembangan Phytophthora palmivora pada buah kakao. Agroland. 16:9-16.

Wahono SK, Damayanti E, Rosyida VT, Sadasyuti EI. 2011. laju pertumbuhan Saccharomyces cerevisiae pada proses fermentasi pembentukan bioethanol dari biji shorgum (Sorghum bicolor L.). In: Seminar Rekayasa Kimia dan Proses. Semarang (Indones): University of Diponegoro.

Wina E. 2005. Teknologi pemanfaatan mikroorganisme dalam pakan untuk meningkatkan produktivitas ternak ruminansia di Indonesia. WARTAZOA. 15:173-186.

Yunianta, Hartatik. 2015. The Use of Trichoderma sp. as a Starter of Fermentation Dry Teak Leaves (Tectona grandis) as Animal Feed. In: 6th Int Semin Trop Anim Prod Integr Approach Dev Sustain Trop Anim Prod. Yogyakarta (Indones): Faculty of Animal Science Universitas Gadjah Mada.

Zakaria, Thamrin A, Lestari RS, Hartono R. 2013. Pemanfaatan Tepung Kelor (Moringa oleifera) dalam Formulasi Pembuatan Makanan Pada Balita Gizi Kurang. Media Gizi Pangan. 14:1-6. 